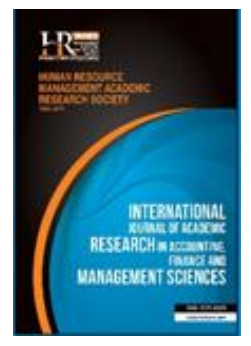

International Journal of Academic Research in Accounting, Finance and Management Sciences

Vol. 9, No.3, July 2019, pp. 192-200

E-ISSN: 2225-8329, P-ISSN: 2308-0337

(c) 2019 HRMARS

www.hrmars.com

To cite this article: Al matarneh, G. F. (2019). The Impact of Sustainability Dimensions in Improving the Quality of Financial Disclosure of Jordanian Shareholding Industrial Companies from the Point of View of External Jordanian Auditors, International Journal of Academic Research in Accounting, Finance and Management Sciences 9 (3): $192-$ 200

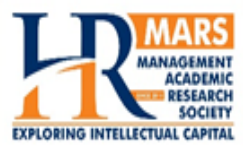

\title{
The Impact of Sustainability Dimensions in Improving the Quality of Financial Disclosure of Jordanian Shareholding Industrial Companies from the Point of View of External Jordanian Auditors
}

\author{
Ghassan F. Al Matarneh \\ Faculty of Economics and Business Administrative, Accounting Dept., Al-al-bayt University, Mafraq, Jordan \\ E-mail:dr_matarneh@hotmail.com
}

\begin{abstract}
The main objectives of the study are to examine the impact of the, environmental (EN), social (SC) and economic (EC) dimension on the quality of financial disclosure. And provides evidence whether the sustainability dimensions are affecting the quality of financial disclosure. To accomplish these objectives, a questionnaire was designed and distributed to a sample of Jordanian external auditors. The results of the questionnaire indicate that external auditors in Jordan consider the environmental, social and economic dimensions as important factors affecting the quality of financial disclosure. It was found that "social dimension" had the highest mean score (4.267), followed by "economic dimension" (4.195) and "environmental dimension" (4.007). The study recommended that Jordanian shareholding companies must work to ensure the availability of the key factors to achieve the quality of financial discloser.

Key words Sustainability Dimensions, Financial Disclosure, Jordan, Quality

Received: 30 Aug $2019 \quad$ (C) The Authors 2019

Revised: 14 Sep 2019 Published by Human Resource Management Academic Research Society (www.hrmars.com)

Accepted: 18 Sep 2019 This article is published under the Creative Commons Attribution (CC BY 4.0) license. Anyone may Published Online: $25 \mathrm{Sep} 2019 \quad$ reproduce, distribute, translate and create derivative works of this article (for both commercial and non-commercial purposes), subject to full attribution to the original publication and authors. The full terms of this license may be seen at: http://creativecommons.org/licences/by/4.0/legalcode
\end{abstract}

\section{Introduction}

The term sustainability has been used since the eighties of the twentieth century. It has been defined by the United Nations for Environment and Development on 20 March 1987: "Sustainable development is that meets the needs of the present time without compromising the ability of future generations to meet their own needs (United Nation, 1987). To achieving the sustainability requires the reconciliation of social, environmental and economic demands.

To face the Jordanian shareholding industrial companies' competitive global and improving its profitability must have attention to the sustainability dimensions, and the pursuit of these dimensions to improving the quality of financial disclosure to survive and continue, and consequently lead to creates new and appropriate investments. Therefore this study aims to provide evidence on the question of whether the sustainability dimensions, economic, environmental, and social effect the quality of financial disclosure. This is achieved by examining the impact of these factors on the quality of financial disclosure. 


\subsection{Research questions}

Jordanian shareholding industrial Companies are seeking to improve its quality of financial disclosure through sustainability dimensions, therefore it has to include all activities and processes that ensure sustainability that related with environmental, economic and social areas. Accordingly, the purpose of this study is to look at the impact of sustainability dimensions to improve the quality of financial disclosure of these companies. Therefore the study seeks to answer the following questions:

1 Is the Environmental dimension impact the quality of financial disclosure of Jordanian shareholding industrial companies?

2 Is the social dimension impact the quality of financial disclosure of Jordanian shareholding industrial companies?

3 Is the Economic dimension impact the quality of financial disclosure of Jordanian shareholding industrial companies?

\subsection{Objectives of the study}

The main objectives of this study are:

1. To know the impact of environmental dimension on the quality of financial disclosure of Jordanian shareholding industrial companies.

2. To know the impact of social dimension on the quality of financial disclosure of Jordanian shareholding industrial companies.

3. To know the impact of economic dimension on the quality of financial disclosure of Jordanian shareholding industrial companies.

\subsection{Significance of the study}

Sustainability dimensions have become important factors in the world, especially among companies that required fulfilling the responsibilities of environmental, social and economic. Therefore the importance of this study is to looking at the impact of the sustainability dimensions in improving the quality of financial disclosure in the Jordanian shareholding industrial companies, through indicators made for the purposes of the study.

\section{Literature review}

Study of Caesaria and Basuki (2017) aimed to investigate the effect of Sustainability Report Disclosure to the Firm's market performance. Three material aspects disclosed in the Sustainability report such as economics (EC), environmental (EN), and social aspect (SC) are used as the independent variables in this research and, furthermore, the dependent variable is the market performance which is peroxide by using Tobin's $Q$. This research was conducted using mainstream positivistic quantitative methods to test the three formulated hypotheses. The samples taken were 44 observations from all listed companies in the Indonesia Stock Exchange (IDX) that reveal sustainability reports using GRI-G4 guidelines. This guideline is the latest version issued by the Global Reporting Initiative (GRI), which can be implemented starting from 2013. The results showed that economics, environmental, and social aspects have positively significant influence to the company's market performance. The practical implication of this research is the value given by society in term of the company image to those companies which disclosure their activities related to economics, social, and environment activities affects their company performance.

Paper of Linzatti and Ossmann (2017) aims to reveal whether selected universities in Australia and Austria meet the reporting expectations about their activities on sustainability in very heterogeneous environments. The results reveal that the universities concentrate on economic information, preferably on accounting, whereas social aspects are of second importance. Environmental activities that essentially shape the image of sustainability for the majority of the stakeholders are mostly unattended.

Rawan (2016) study aims to look at the impact of the disclosure of the three dimensions of sustainability reports (economic dimension, environmental dimension, social dimension) on the financial performance of the Jordanian commercial banks represented by (return on assets, return on equity and earnings per share) amounting to a number (13) banks, based on the general framework of the global 
initiative for sustainability report. The researcher followed the content analysis method. For the purpose of the study analysis tool, has been relying on descriptive statistics, analysis of multiple linear regression. The study found a number of the most important results and no significant impact for the disclosure of the economic and social dimension of the financial performance represented the return on assets, and the presence of significant effect for the disclosure of the economic dimension of the financial performance represented the return on equity, in addition to having a significant impact for the disclosure of economic, environmental and social dimension the financial performance represented the return on the stock. The study recommended the need to encourage Jordanian commercial banks and stimulated toward issuing sustainability reports, pay Jordanian commercial banks so much attention to disclose the environmental dimension, and the disclosure of the role played by Jordanian commercial banks in the environmental fields.

The study of Zyadat (2016) looked into the effect of the three dimensions of sustainability (economic dimension, environmental dimension, and social dimension) on the financial performance of Jordanian Islamic banks represented by (return on assets, return on equity, and earnings per share) during the period (2008-2014). The study results have shown the presence of a statistically significant effect of the dimensions of sustainability on the financial performance measured by ROA and EPS in the Jordanian Islamic banks. However, there was no statistically significant effect of the dimensions of sustainability on the financial performance as measured by ROE in those banks. Finally, the study has encouraged Islamic banks to adopt a rational and prudent investment and financial policies, make proper operational decisions to generate revenue, maximize profits, and achieve shareholder objectives, issue sustainability reports to discover if goals and activities are compatible to the goals and interests of society and the environment, and increase their interest in sustainability.

Study of Lin et al. (2014) explored how users and preparers rated the importance of performance indicators suggested by the Global Reporting Initiative (GRI) Guidelines regarding the environmental, economic and social impacts of a company. It provides evidence on which GRI performance indicators are perceived as relevant and important by both preparers and users. We found that users and preparers generally agree with the relevance and importance of all the performance indicators included in the GRI G3 guidelines. Despite a few areas of statistical disagreement, the overall perceptions were similar between users versus preparers regarding the importance of the GRI indicators. The convergence of the usefulness of GRI guidelines as viewed by the two conflicting stakeholders of users and preparers suggests that the stage may be ready for rule-making bodies and governmental agencies to further promote sustainability reporting by mandating uniform standards in reporting and disclosure.

Study of Krechovska, and Prochazkova (2014) discusses corporate governance and its necessary change with regard to trends in society, especially in view of the concept of sustainability. Corporate sustainability is understood as the ability of companies to positively influence environmental, social and economic development through their governance practices and market presence. The approach of enterprises to sustainability and the level of integration of sustainability into corporate governance where examined by the author empirical research conducted among enterprises in the Czech Republic in 2012. It was found that enterprises are aware of the importance of the concept of sustainability to achieve corporate performance in the long term. However, sustainability is not integrated into individual business processes (especially by small and medium-sized enterprises), as research results demonstrated. Focus on the company's financial results is prevalent. Many enterprises do not work with sustainability within corporate strategy and management, and neither do they include sustainability in performance measurement and management. Reporting of sustainable corporate activities is very simple, especially for SMEs. A prerequisite for fully functioning corporate governance with regard to sustainability is a reflection of sustainability through the whole process of business management. Sustainability should become an integral part of strategic management and corporate planning.

The objective of Ching et al. (2013) study is to examine the quality of information disclosed from a sample of Brazilian listed companies, using a multidimensional construct based on economic, environmental and social dimensions of sustainability. The research design combines both quantitative and qualitative methods. The qualitative approach is used in the content analysis procedure and the quantitative is employed for statistical analysis. The target population consists of top 36 sustainable 
companies (ISE) and 24 with corporate governance practices (NM) in 2011 . We find that $37 \%$ of the companies achieved score above $0.5 ; 30 \%$ between 0.26 and 0.5 and $33 \%$ scored below 0.25 , being score zero the worst and one the best score. The best company scored 0.896 and the worst of the 60 companies scored 0.0167. Overall our statistical results confirm that ISE companies tend to disclose more information and in a more adequate way than NM, and in general, the companies are reporting the content in all the three dimensions with same quality level. Furthermore, companies from Infrastructure sector present better quality content reported when compared to Service companies. We conclude that a good sustainability report is directly related to the good content in all the tree dimensions, regardless the economic sector and these reports still have a big room for improvement, which echoes within the literature analyzed. Companies need to disclose their information in a more integrated way, addressing sustainability issues under the scope of business strategy.

\section{Theoretical frameworks}

\subsection{Sustainability}

Sustainability has been defined by the organizations as the capacity of the organization to adopt additional activities and actions to address the events and changes related to the economic, social and environmental, and to manage the resulting risks that affect its reputation and existence, as well as managing the commitments and opportunities that motivate them to innovate and increase their resilience to their internal and external environment (Bansal \& Ivey, 2013). The global interest in sustainability was demonstrated by the initiatives of many countries to convene committees and conferences on sustainability and sustainable development, the first of it was the Earth Summit held in 1992 in the capital Brazil (Rio de Janeiro), which resulted in the adoption of a plan of action by the nations of the world to achieve sustainable development during the twenty-first Century (Davidson, 2010).

In response of the global calls on the effect of environmental, economic and social activities on the work of enterprises and organizations, and the need to disclose the risks and threats that may affect the current and future performance, income and value of companies, as well as highlighted the facts and financial information about them, because the traditional accounting reports do not meet the needs of beneficiaries of the information and data relating to these matters; therefore issuing special reports called it (sustainability reporting) the Global Initiative for Global Reporting Initiative(GRI) has come in 1997, to urge all organizations to disclose the overall sustainability items, and included special reports, in order to increase the level of transparency in all organizations around the world included the general framework of this report which was adopted this initiative principles guidelines and standards for sustainability reporting, which enable organizations to report on the economic, environmental and social performance. Hence it is imperative for companies and stakeholders to accept this approach whether it's a legal or optional manner.

The world summit of United Nations held in 2005 promotes the integration of the three components of sustainable dimensions that are (United Nations General Assembly, 2005):

1. Environmental dimension: This dimension is defined as the overall activities and actions of the organization that would limit the negative environmental impacts, this dimension focuses on the protection of ecosystems (land, air and water), maintain of energy sources, access to renewable resources.

2. Economic dimension: This dimension focuses on achieving the sustainability of economic construction through capital efficiency and resource utilization, securing the basic needs and requirements of the individual and improving his standard of living by maximizing the returns he has to achieve from products and services.

3. Social dimension: This dimension focuses on achieving social justice and equity in the distribution of natural and economic resources, promoting social interaction and participation in local communities, developing cultural diversity, and caring for human rights.

Sustainability is turning into a core business strategy over time, representing a common trend for every big company. Companies are starting to view the sustainable side of their activities as an important performance assessment. Sustainability has been introduced as a new reporting subject for the companies worldwide in the last few years additionally to financial information. According to KPMG (2011), 95\% of the 250 largest companies around the world have already published reports on the subject, compared to only 
$45 \%$ in 2002. It is clear that the so-called sustainability reports turned into common practice and an essential document for every company that is looking for a sustainable image (Ching and Toste. 2013).

Investors are also paying attention to the stock price performance of sustainable companies. Studies

linking financial performance and/or performance indicators with sustainable practices or corporate social responsibility practices have been conducted by some authors (Ameer and Othman, 2012; López, et al, 2007).

\subsection{Quality of financial disclosure}

The primary objective of financial reporting is to provide high-quality financial reporting information concerning economic entities, primarily financial in nature, useful for economic decision making. According to IASB, the essential principle of assessing the financial reporting quality is related to the faithfulness of the objectives and quality of disclosed information in a company's financial reports. These qualitative characteristics enhance the facilitation of assessing the usefulness of financial reports, which will also lead to a high level of quality (Herath and albarqi, 2017).

To achieve this level, financial reports must be faithfully represented, comparable, verifiable, timely, and understandable. Thus, the emphasis is on having transparent financial reports, and not having misleading financial reports to users; not to mention the importance of preciseness and predictability as indicators of a high financial reporting quality (Mirla and Andra, 2015).

Financial reporting quality (FRQ) is generally characterized under two different approaches, namely, "users' demand" and "investor protection". The former considers the needs of the users of financial information and determines the quality of financial reporting according to the usefulness of financial reports from users' viewpoint. The latter focuses on providing further impetus for investment and primarily uses the completeness and fairness of disclosures for shareholders as proxies for FRQ. More specifically, the second approach puts emphasis on the transparency and completeness of financial disclosures, the degree of conservatism and estimates used in accounting information and the consistency and comparability of financial records as major FRQ proxies (Salehi and Shirazi, 2016).

\section{Research methodology and Hypothesis}

\subsection{Research methodology}

The research depended on the method of analytical statistics and analysis of content, and on secondary and primary data. Secondary data for the study were obtained through reference, research, and universities research papers. For the initial data, they were collected through a questionnaire, which is designed depending on the nature of the elements of the problem which is available in literature reviews. The statistical descriptive style analysis technique also the content analysis has been used to achieve the objectives of the study. The survey questionnaire contains two parts, first part included demographic characteristics, the second part covers the responders' commitment, each set questions formed a field paragraph, which covers the questions of the study. Five-Likert scale has been used as a measure of reflect the views of respondents regarding the paragraphs contained in the questionnaire, which was allocated weight (5) for the situation strongly agree, and (4) for agree, and (3) for the situation is neutral and (2) for disagree, and (1) for Strongly Disagree. the questionnaire has introduced to a group of professionals and professors for the purpose of arbitration, where they can modify it based on their observations and a previous test was conducted on it, and the amount of Cronbach's alpha were reached (.816) which is indicated on the consistency and steadfastness (Sekaran, 2015). And arithmetic mean, standard deviation and percentages were used in the quarterly analysis of the responses to the questionnaire

\subsection{Research Hypothesis}

Research seeks to test the following hypothesis:

H1.There is an impact of Environmental dimension on improving quality of financial disclosure of Jordanian Shareholding industrial companies.

H2. There is an impact of Social dimension on improving quality of financial disclosure of Jordanian Shareholding industrial companies. 
H3. There is an impact of Economic dimension on improving quality of financial disclosure of Jordanian Shareholding industrial companies.

Sample of External auditors

A comprehensive containing method for the study population consists of the Jordanian auditors of the sum of (422), the total number of questionnaires distributed to auditors who audit the Jordanian shareholders industrial companies was (92) questionnaire, including (87) questionnaire valid for analysis, and thus the percentage of the collected questionnaires were (\%95).

\section{Results of the study}

\subsection{Characteristics of respondents}

The demographical characteristics are described for the respondents and analyze their opinions and responses on the survey questionnaire, and the arithmetic means and standard deviations were extracted from their responses for each field of the questionnaire table (1) shows that 50 respondents or 57 percent hold a bachelor degree and 27 respondents or 31 percent have a master certificate, As for the area of study, the overwhelming majority of the respondents 78 percent have an academic degree in accounting, and 12,10 percent have finance, business administrative certificate respectively. It can also be seen from the table that the majority of responders 86 percent have had experience in auditing for more than five years. Overall, the table information indicates that they are qualified to answer the questionnaire and can be trusted in their abilities and information.

Table 1. Demographic distribution of the respondents

\begin{tabular}{llccc}
\hline Variable & Categories & \multicolumn{2}{c}{ Frequency } & $\%$ \\
\hline Qualifications & Bachelor's Degree & 50 & 57 \\
& Higher Diploma & 10 & 12 \\
& Master's Degree & 27 & 31 \\
Specialization & Accounting & 68 & 78 \\
& Finance & 10 & 12 \\
& Business Administrative & 9 & 10 \\
Expenience & less than 5 years & 12 & 14 \\
& From 5-10years & 20 & 23 \\
& From 10-15years & 17 & 20 \\
& From 15-20years & 16 & 18 \\
& More than 20 years & 22 & 25
\end{tabular}

\subsection{Descriptive statistics}

Impact of Environmental dimension

Table 2 shows the impact of environmental dimension on improving quality of financial disclosure of Jordanian shareholding industrial companies, ten paragraphs were used to this dimension, and the table provides the results of the questionnaire concerning the level of impact given by external auditors to each paragraph. 
Table 2. Impact of following environmental elements in improving the quality of financial disclosure.

\begin{tabular}{|c|l|c|c|}
\hline \multicolumn{1}{|c|}{ Paragraph } & Mean & SD \\
\hline 1 & Greenhouse gases emissions from energy consumption & 4.046 & .6453 \\
\hline 2 & Solid and liquid waste resulting from industrial processes & 3.954 & .8199 \\
\hline 3 & $\begin{array}{l}\text { Environmental effects on the transfer of products and materials required for } \\
\text { operations }\end{array}$ & 4.241 & .7308 \\
\hline 4 & Discloses the total cost of disposal of waste that harmful the environment & 4.172 & .7023 \\
\hline 5 & $\begin{array}{l}\text { Financial value of fines due to non-compliance with environmental regulations } \\
\text { and laws }\end{array}$ & 4.322 & .5602 \\
\hline 6 & Energy consumption by the company & 3.862 & .8237 \\
\hline 7 & Disclose the volume of consumption of natural resources & 3.690 & .7519 \\
\hline 8 & Percentage of materials used from recycled materials & 4.195 & .6619 \\
\hline 9 & The company acquires new sources of energy & 3.839 & .6264 \\
\hline 10 & Disclosing any policies relating to environmental accounting & 3.747 & .7188 \\
\hline & Total Field & $\mathbf{4 . 0 0 7}$ & $\mathbf{0 . 7 0 4 1}$ \\
\hline
\end{tabular}

As can be seen from the table, the overwhelming majority of the respondents consider elements such as the financial value of fines due to non-compliance with environmental regulations and laws, transference of products and materials, percentage of materials used from recycled materials, total cost of disposal of waste that harmful the environment, greenhouse gases emissions from energy consumption. The arithmetic means of the respondent's answers of this field are high reached to (4.007), and the standard deviations were (0.7041).

\section{Impact of Social dimension}

Table 3 shows the impact of social dimension on improving quality of financial disclosure of Jordanian shareholding industrial companies, eight paragraphs were used to this dimension, and the table provides the results of the questionnaire concerning the level of impact given by external auditors to each paragraph. As can be seen from the table, the overwhelming majority of the respondents consider elements such as the company takes care of health and safety products for customers, information that contributes to the provision of employment and treatment of unemployment, product safety costs, staff training costs and skills required, costs of treatment of work injuries. The arithmetic means of the respondent's answers of this field are high reached to (4.267), and the standard deviations were (0.7430).

Table 3. Impact of following social elements in improving the quality of financial disclosure

\begin{tabular}{|c|l|c|c|}
\hline & \multicolumn{1}{|c|}{ Paragraph } & Mean & SD \\
\hline 1 & Value of donations and assistance to charitable organizations and societies. & 4.046 & .8340 \\
\hline 2 & Staff training costs and skills required. & 4.356 & .6096 \\
\hline 3 & $\begin{array}{l}\text { Information that contributes to the provision of employment and treatment of } \\
\text { unemployment. }\end{array}$ & 4.494 & .7606 \\
\hline 4 & Improve the physical and service working conditions of their employees. & 4.034 & .9332 \\
\hline 5 & The company takes care of health and safety products for customers & 4.563 & .6043 \\
\hline 6 & Costs of treatment of work injuries. & 4.149 & .8830 \\
\hline 7 & Product safety costs. & 4.379 & .6332 \\
\hline 8 & Statement of accounting treatment of social responsibilities & 4.115 & .6892 \\
\hline & Total Field & $\mathbf{4 . 2 6 7}$ & $\mathbf{0 . 7 4 3 0}$ \\
\hline
\end{tabular}

\section{Impact of economic dimension}

Table 4 shows the impact of economic dimension on improving quality of financial disclosure of Jordanian shareholding industrial companies, eight paragraphs were used to this dimension, and the table provides the results of the questionnaire concerning the level of impact given by external auditors to each paragraph. As can be seen from the table, the overwhelming majority of the respondents consider elements such as innovative methods that work to raise the efficiency and economy of the company, financial assistance received from the government, Percentage of expenditure on suppliers, the market 
share of the company. The arithmetic means of the respondent's answers of this field are high reached to (4.195), and the standard deviations were (0.7012).

Table 4. Impact of following economic elements in improving the quality of financial disclosure

\begin{tabular}{|c|l|c|c|}
\hline & \multicolumn{1}{|c|}{ Paragraph } & Mean & SD \\
\hline 1 & The economic value generated by the capital & 3.977 & .7621 \\
\hline 2 & Financial assistance received from the government & 4.322 & .5602 \\
\hline 3 & Financial impacts of climate change & 4.023 & .8066 \\
\hline 4 & The market share of the company & 4.184 & .6739 \\
\hline 5 & Costs of contributions to the development of the national economy & 4.276 & .6230 \\
\hline 6 & Innovative methods that work to raise the efficiency and economy of the company & 4.368 & .7489 \\
\hline 7 & Percentage of expenditure on suppliers & 4.241 & .7308 \\
\hline 8 & The ability of the company to use the economic resources available to it & 4.172 & .7023 \\
\hline & Total Field & $\mathbf{4 . 1 9 5}$ & $\mathbf{0 . 7 0 1 2}$ \\
\hline
\end{tabular}

\section{Testing research hypotheses}

(T) test was used to test the hypothesis of the study, and table (5) illustrates the test results for all the hypotheses of it, the decision rule has been adopted to accept the alternative hypothesis and reject the null hypothesis if the calculated $(T)$ value was greater than the indexed $(T)$, and accept the null hypothesis and reject the alternative hypothesis if the calculated $(T)$ value was less than the indexed $(T)$ value at the level of significance (0.05).

The results of $(T)$ test showed that the calculated $(T)$ values were greater than the indexed values for the Hypotheses no (1), (2), and (3), as the calculated (T) value was (120.918) for the hypothesis of impact of environmental dimension in improving the quality of financial disclosure. Also the impact of social dimension in improving the quality of financial disclosure, $(T)$ value was (117.058).And the hypothesis of impact of economic dimension in improving the quality of financial disclosure (T) value was (94.822). In accordance with the decision rule, the null hypotheses were rejected, and the alternative hypotheses were accepted for all hypotheses.

Table 5. Testing Hypotheses

\begin{tabular}{lrrr}
\hline The hypothesis & $\begin{array}{c}\text { Arithmetic } \\
\text { Mean }\end{array}$ & Calculated T & $\begin{array}{c}\text { Result of null Hypothesis } \\
\text { test }\end{array}$ \\
\hline $\begin{array}{l}\text { Impact of environmental dimension. } \\
\text { Impact of social dimension. }\end{array}$ & 4.007 & 120.918 & Rejected \\
Impact of economic diminution. & 4.195 & 117.058 & Rejected \\
\end{tabular}

\section{Conclusions}

The objectives of this study were:

- To examine the impact, if any, of the environmental, social and, economic dimensions in improving the quality of financial discloser.

- To provides evidence whether the environmental, social and, economic dimensions, determine quality of financial discloser.

To accomplish these objectives, a questionnaire was designed and distributed to a sample of Jordanian external auditors. The results of the questionnaire indicate that external auditors consider environmental, social and, economic dimensions as important factors affecting the quality of financial discloser. It was found that "social" had the highest mean score (4.267), followed by "economic" (4.195) and "environmental" (4.007). As for the second objective, a (T) test reveals the degree of impact variables at the improving the quality of financial discloser. The results of $(T)$ test indicated that environmental dimension is the most important variable affect the improving the quality of financial discloser, social is the 
second factor affecting the improving the quality of financial discloser, and the economic is the lower factor affecting the improving the quality of financial discloser.

The study recommended that Jordanian shareholding companies must work to ensure the availability of the key factors to achieve the quality of financial discloser. Checking the quality of the financial discloser by the external parties possess the expertise in this area, such as financial analysts, external auditors, to ensure the availability of environmental, social and, economic dimensions in acceptable level in the financial statements. Also the researcher recommends and emphasis that the Jordanian shareholding companies must compliance with the rules, and standards.

\section{References}

1. Aisyah, F. C., and B. Basuki, (2017). The study of sustainability report disclosure aspects and their impact on the companies' performance, SHS Web of Conferences, 34, 08001.

2. Abdelfattah, A. H. Z. (2016). The Impact of Sustainability on the Financial Performance of Jordanian Islamic Banks, International Journal of Economics and Finance; 9(1); doi:10.5539/ijef.v9n1p55.

3. Bansal, T. \& Ivey, R. (2013). The Financial Times Ltd. School of Business, University of Western Ontario.

4. Davidson, K. (2010). Reporting Systems for Sustainability: What are they measuring? Springer Science \& Business Media, B.V.

5. Farhan, R. (2016). The Impact of Disclosure of the Dimensions of Sustainable Reporting on the Financial Performance of the Jordanian Commercial Banks, unpuplished thesis, Amman Arab university.

6. Hong, Y. C., Gerab, F. \& Thiago, T. (2013). Analysis of Sustainability Reports and Quality of Information Disclosed of Top Brazilian Companies, International Business Research; Vol. 6, No. 10; doi:10.5539/ibr.v6n10p62.

7. Hsiang (Hank), L., Otto, H. C., \& Chunchia, (Amy) C. (2014). Importance of Sustainability Performance Indicators as Perceived by the Users and Preparers: Journal of Management and Sustainability; Vol. 4, No. 1; doi:10.5539/jms.v4n1p29.

8. López, M. V., Garcia, A., \& Rodriguez, L, (2007). Sustainable Development and Corporate Performance: A Study Based on the Dow Jones Sustainability Index. Journal of Business Ethics, 75, 285300.;doi.org/10.1007/s10551-006-9253-8.

9. Mahdi, S., \& Mohammadamin, S. (2016). Audit committee impact on the quality of financial reporting and disclosure (Evidence from the Tehran Stock Exchange), Management Research Review, Vol. 39 Issue.12;doi.org/10.1108/MRR-09-2015-0198.

10.Krechovska, M., Prochazkova, P. T. (2014). Sustainability and its Integration into Corporate Governance Focusing on Corporate Performance Management and Reporting, Procedia Engineering, 69; doi: 10.1016/j.proeng.2014.03.103.

11.Schaffhauser-Linzatti, M. M., Ossmann, S. F. (2017). Sustainability in higher education's annual reports an empirical study on Australian and Austrian universities, International Journal of Sustainability in Higher Education; Vol. 19 Issue: 2, doi.org/10.1108/IJSHE-05-2016-0093.

12.Nichita, M. \& Gajevzsky, A. (2015). Evolution and Quality of Financial Reporting In Romania: An Overview from 1990 to Present, Annals of Faculty of Economics University of Oradea, Faculty of Economics, vol. 1(1)

13.Siriyama, H. \& Norah, A. (2017). Financial Reporting Quality: A Literature Review, International Journal of Business Management and Commerce; Vol. 2 No. 2; March.

14.Uma, S. (2015). Research Methods for Business: A Skill Building Approach. (9th Edition). New York: John Wiley and Sons Inc.

15.United Nations General Assembly (2005). World Summit Outcome, Resolution A/60/1. Adopted by the General Assembly on 15 September 2005.

16.United Nations (1987). Report of the United Nations High Commissioner for Environment and Development: Our Common Future" Chapter 2: Towards Sustainable Development. 